\title{
An investigation on loyalty formation model in e-banking customers: A case study of banking industry
}

\author{
Mahmood Reza Esmaeili ${ }^{\mathrm{a}}$, Amir Hooshang Nazarpoori ${ }^{\mathrm{a}^{*}}$ and Masumeh Najafi ${ }^{\mathrm{b}}$
}

\begin{abstract}
${ }^{a}$ Assistant professor, Department of Management, Lorestan University, Lorestan, Iran
${ }^{b}$ M.A in Business Management, Lorestan University, Lorestan, Iran

\section{H R O N I C L E}

Article history:

Received October 12, 2012

Received in revised format

22 January 2013

Accepted 23 January 2013

Available online

January 252013

Keywords:

E-satisfaction

E-trust

E-loyalty

Confirmation/disconfirmation

theory

Structural equation model (SEM)

\section{A B S T R A C T}

E-banking plays an important role on increasing customer satisfaction and helps industry grow faster. Most banks try to retain their customers by introducing more electronic services to facilitate banking transactions. Creating loyalty through providing better banking services is a new area of research. In fact, e-loyalty can be directly impacted by e-satisfaction, e-trust, and indirectly influenced by e-services, perceived value, reputation, and habit. Therefore, the present paper deals with designing and explanation of loyalty formation model in e-banking. The preliminary results indicate that "satisfaction" is the most influential component affecting customer loyalty formation with an $87 \%$ diagnose coefficient. In addition, trust formation in customers may impact loyalty in an electronic environment with a $70 \%$ diagnose coefficient. Moreover, the most important factors impacting customer satisfaction include "reputation" "perceived value," "service quality," and "habit" with relative effects coefficients of $44 \%$, $32 \%, 29 \%$, and $26 \%$, respectively. Finally, "reputation," "service quality," "habit" and "perceived value" have been the most important factors influencing customer trust with influence coefficients of $37 \%, 32 \%, 31 \%$, and $24 \%$, respectively.
\end{abstract}

(C) 2013 Growing Science Ltd. All rights reserved.

\section{Introduction}

Loyalty has been a primary concern in marketing planning for different reasons including global competition, market saturation, technological development, and customer awareness. In fact, a longterm success is not just a function of fair price but it is a function of quality of products and services and many corporations prefer to build a long-term relationship with their customers using customeroriented preferences. Thus, it is important to increase and retain loyal customers, which may serve as a main factor in long-term success of corporations. Corporations attempt to absorb and satisfy customers and develop a long-term relationship through creating loyalty among them (Akhter et al.; 2011). Beerlie et al. (2004) stated that most banks nowadays provide similar services, and products do not have particular characteristics to keep their customers loyal (Ghane et al., 2011). Thus,

*Corresponding author. Tel: +989163975706, Fax: +98661-6200102

E-mail addresses: ah_nazarpoori@yahoo.com, ahnazarpoori@gmail.com (A. Nazarpoori) 
customer preservation is a very useful instrument where banks may use to obtain a strategic advantage, and stay in today's banking environment, which is increasingly becoming competitive (Cohn et al., 2006). Cognition of loyalty concepts is very crucial because customer loyalty plays essential role in organizational growth. Studies show that e-loyalty is directly influenced by e-service quality, perceived value, reputation, and habit. Therefore, this research intends to study the factors influencing customer loyalty in e-banking.

\section{Loyalty concept}

Considering the challenges, which are prevalent in the business atmosphere, organizations do not merely intend to "absorb new customers" but they have adopted the strategy of "preserving the existing customers and promoting their loyalty to the organization". Therefore, customer satisfaction is no longer sufficient, and marketing people have to pave the way for improvement and promotion of customers' loyalty in the arena of customer-centeredness. Loyalty originates from belief in service quality, psychological decision (i.e., behavioral intention), as well as desired positive attitude, and is perceived as purchase behavior repetition and stability in purchase behavior (Castro et al., 2004). Today, preservation and reinforcement of customers' loyalty is described as a strategic challenge for the corporations concerned about maintenance and development of their competitive status in the market. Consequently, they spend significant amount of expenditures for understanding and recognizing this concept, and obtaining applied strategies to reinforce it.

Prior to defining customer loyalty, we have to know whether loyalty is a behavior standard or an attitude standard. Behavioral loyalty tries to describe brand loyalty based on real observed purchases in a specified time, whereas attitude loyalty standards are based on certain priorities, commitment, or intention for purchase. Attitude commitment includes a desired fixed set of specific beliefs about the purchased brand. The intensity of these attitudes is an important factor in purchasing and supporting a brand (Larsson et al., 2004). Oliver defined customer loyalty as "deep commitment in re-purchasing and supporting a selected product or service in future despite situational effects and marketing attempts to change customer behavior" (Methlie, \& Nysveen, 1999). Beerlie et al. (2004) believed that there was another dimension of loyalty known as compulsory dimension, stating that loyalty was habitual and staying with a specific trademark is better for a customer than consuming energy to change it. In addition, many researchers have differentiated between effective and interactive loyalties. Interactive loyalty means that customer prefers to use the bank in future as well, while effective loyalty states how much a customer likes the bank and what his attitude towards the bank is. Bloemer et al. (1988) stated that the results from research on product loyalty could not be applicable to service loyalty, because service loyalty implements to customer-clerk relationship (Ericson et al., 2009).

\section{Electronic banking}

E-banking is a special type of banking service, which was first implemented in the United States in 1995, developed quickly among other business units. E-banking is a wave to bring convenience and economy for customers and such new challenges for officials as security, inaccessibility to enetworks due to faults, maintenance cost, updating databases, as well as planning and executing modern economic policies. E-banking is an application of electronic instruments, which includes internet, wireless networks, ATMs, telephones, and cell phones to provide banking services and products (Abbasnejad, 2006). E-banking includes the systems, which enables customers of financial institutions to implement banking services at three levels including notification, communication, and transaction (Ghane et al., 2010).

\subsection{Electronic loyalty}

E-loyalty is defined as customers' willingness to revisit an electronic business based on their past experiences and future expectations (adopted from Czepie et al., 1987). Ivanov et al. (2007) defined 
electronic loyalty as "intending to visit and use a website again or interact through it in future". Strauss and Frost (2001) recommended that the main emphasis of e-loyalty can be described based on changing behavioral motive to immediate purchasing behavior. Chang and Chen (2009) defined eloyalty as "customers' desired attitude toward an e-trade website encouraging the customer to repeat his purchasing behavior". This definition considers customer loyalty as a kind of attitude establishment, and it is very close to real situations (Ghane et al., 2011). In marketing researches and related literature, customer satisfaction is described as an active factor in acquiring customer loyalty (Vahdat \& Mowlaei Najafabadi, 2002). In marketing literature and associated studies on information systems, disconfirmation theory is considered as basis for satisfaction models. According to this theory, satisfaction is described through disconfirmation between the perceived performance and customer's cognitive standards. Fig. 1 demonstrates how satisfaction and loyalty are associated with each other based on expectation-perception disconfirmation theory.

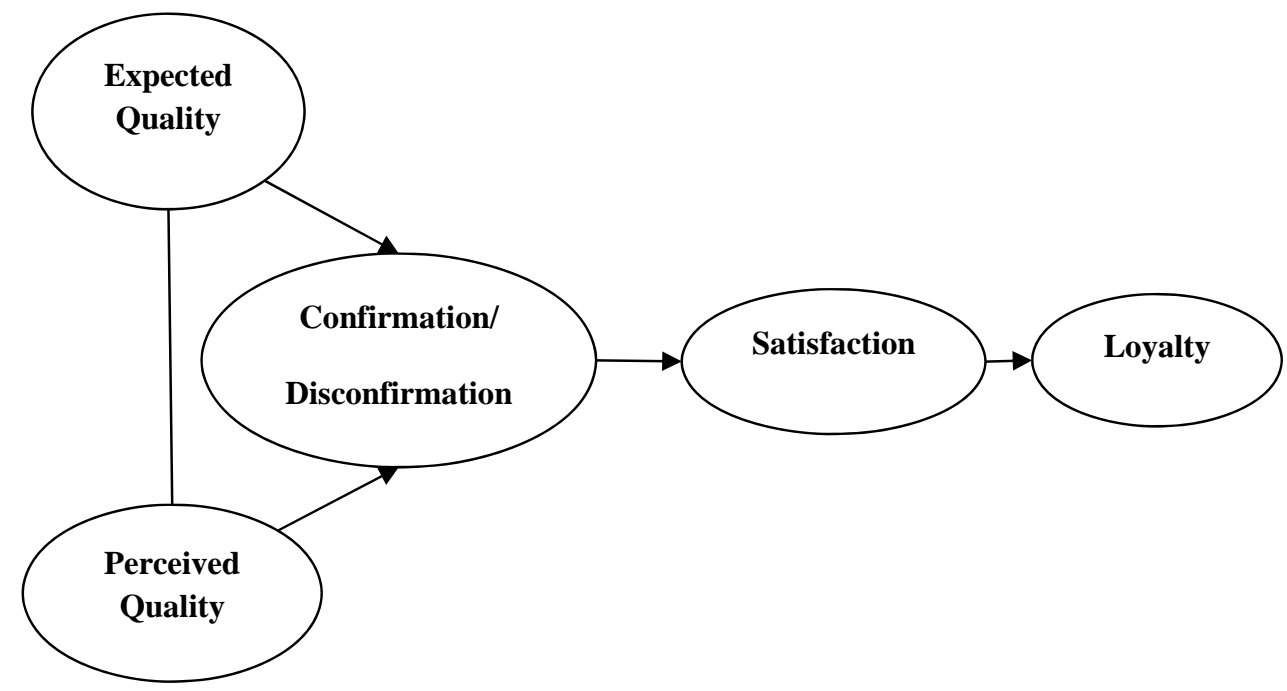

Fig. 1. Expectations - perceptions disconfirmation theory

Expectations can be also defined as customer forecast on what would most probably happen impedingly during the exchange or transaction. In addition, the received performance is explained as customer's perceptions on how a particular product or service fulfills customer's requirements. Disconfirmation can be defined as a customer's mental judgments originating from a fair comparison between customer's expectations and his/her perceptions on received performance. Zeithaml and Bitner (2000) described customer satisfaction as "a customer's evaluation of a product or service to understand whether or not the product or service has met his needs and expectations." They believed that satisfaction had a positive relationship with loyalty, and this impact also occurs in online environment (adopted from Zeithaml \& Bitner, 2000). Shanker et al. (2003) explained in their studies that the impact of satisfaction on loyalty was stronger in online environment than conventional environment. Parasuraman and Zeithaml $(1985,1988)$ believed that in electronic environments where business was concentrated on electronic communications and online exchange processes between purchaser and seller, service quality, perceived value, and customer trust can impact the formation of consistency between customer's relationship with business units, which may lead to loyalty (Yee et al., 2010).

\subsection{Service quality}

Most experienced and successful business units in electronic trade have realized that their success or failure factors would not merely depend on their presence on web or low price, but the important factor of transferring the high quality of electronic services has also a specific factor (Carna et al., 2009). Electronic quality can be described as customers' evaluation of the process and result of 
interaction with an online seller. According to Ribinik (2004) electronic quality includes five dimensions including ease of usage, designing website, ordering, responding, and trust. Service quality is also defined as a customer's belief or attitude concerning the rate of service superiority in the bank environment (Ward et al., 2009).

\subsection{Perceived value}

Perceived value is a strategic instrument to absorb and retain customers based on important factors for the success of industrial corporations and service providers (Gallarza \& Sorae, 2006). Perceived value is a kind of gain where a customer obtains in return for the paid cost.

\subsection{Trust}

Trust is a level of some one's confidence in another party's competence and his/her performance based on predictable ethical principles (Errol et al., 2005). Therefore, electronic trust is the rate of customers' trust in online transactions (Reichheld et al., 2000). Stewart claims that internet failure in electronic banking may be due to the fact that customers would not have trust in electronic channels (adopted from Stewart, 1999). Therefore, customers' trust plays an important role in presupposition for loyalty. Some other people stated that both habit and reputation could influence purchase repetition by a customer and consistency of his relationship with the organization. They believed that acquisition of the required skills in using a website by a customer in e-banking could lead to habit formation (Yee et al., 2010). Habit includes all kinds of phenomena and representation in terms of spiritual activities, as well as material and physical demonstrations. However, they all have something in common because all demonstrations first appeared to be incidental, voluntary or involuntary, become habits due to repetitions and various comparative fluctuations. Then, they have an active involuntary condition and are unconsciously the origin of influence, physically or spiritually, and will become a part of nature after changing into habit (Ordoubari, 1991). A corporation's reputation, according to Herbig (1994), is defined as the stability of its activities in the course of time. Therefore, reputation originates from a corporation's products and services in which trust has the highest importance for evaluating the quality of products and services from customer's perspectives (Paul et al., 2009).

\section{Conceptual model and research question}

Based on the studies conducted on research theoretical principles including confirmation theory, identification of the factors influencing e-loyalty, particularly in e-banking, its conceptual model is developed as Fig. 2.

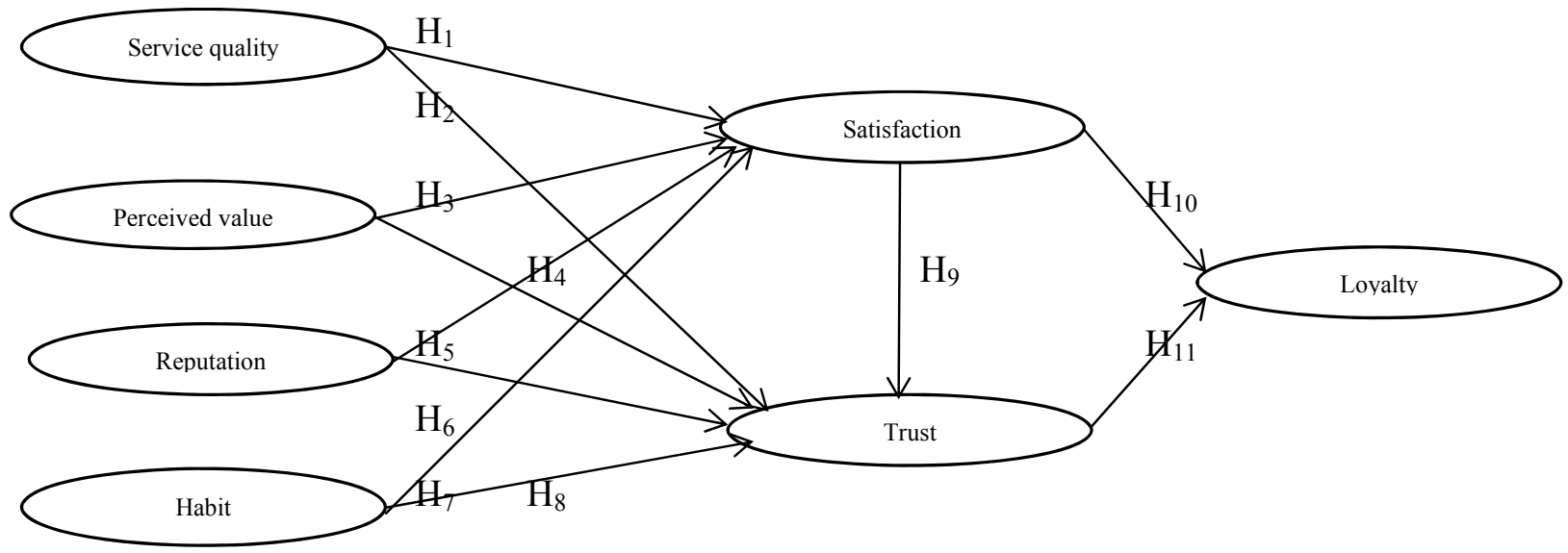

Fig. 2. The framework of the proposed study

According to the conceptual model shown in Fig. 2, research hypotheses are stated as follows: $\mathrm{H}_{1}$ : Service quality influences customer satisfaction in electronic banking. 
$\mathrm{H}_{2}$ : Service quality influences customer trust in electronic banking.

$\mathrm{H}_{3}$ Perceived value influences customer satisfaction in electronic banking.

$\mathrm{H}_{4}$ : Perceived value influences customer trust in electronic banking.

$\mathrm{H}_{5}$ : Habit influences customer satisfaction in electronic banking.

$H_{6}$ : Habit influences customer trust in electronic banking.

$H_{7}$ : Reputation influences customer satisfaction in electronic banking.

$\mathrm{H}_{8}$ : Reputation influences customer trust in electronic banking.

$\mathrm{H}_{9}$ : Satisfaction influences customer trust in electronic banking.

$H_{10}$ : Satisfaction influences customer Loyalty in electronic banking.

$H_{11}$ : Trust influences customer Loyalty in electronic banking.

According to the conceptual model, exogenous structures include service quality, perceived value, habit and reputation, whose measurement criteria are presented in Table 1.

\section{Table 1}

Measurement criteria for exogenous structures

\begin{tabular}{|c|c|c|c|}
\hline Reference & Measurement criteria & Explicit variable & Implicit structure \\
\hline \multirow{3}{*}{$\begin{array}{l}\text { Ouyang, 2010; Santos, } \\
\text { 2003; Ward et al., } 2009\end{array}$} & \multirow{3}{*}{$\begin{array}{l}\text { Presenting the features and functions of services to } \\
\text { users, updating the website information, having a high } \\
\text { uploading of web pages, presenting full information } \\
\text { about features of the product, fulfilling commitments } \\
\text { for customers within certain time limits, providing } \\
\text { services for customers as soon as possible, existence of } \\
\text { information about accessibility of product/ service on } \\
\text { the web, secrecy of customer's information, providing } \\
\text { the customer with clear information about transaction }\end{array}$} & Web design & \multirow[t]{3}{*}{ Service quality } \\
\hline & & Customer service & \\
\hline & & assurance & \\
\hline \multirow{2}{*}{$\begin{array}{l}\text { Woodruff, 1997; } \\
\text { Parasuraman \& Gerowal, } \\
2000\end{array}$} & \multirow{2}{*}{$\begin{array}{l}\text { Suitability of service value in relation to the cost paid } \\
\text { for the service, validating service reception, receiving } \\
\text { the added value due to the electronic services of the } \\
\text { bank }\end{array}$} & Economic value & \multirow[b]{2}{*}{ Perceived value } \\
\hline & & Relation value & \\
\hline \multirow{2}{*}{$\begin{array}{l}\text { Geffen, 2003; Ouyan, } \\
2010\end{array}$} & \multirow{2}{*}{$\begin{array}{l}\text { Customer's image of the bank website as the common } \\
\text { website for banking services, preferring the bank } \\
\text { website to those of other banks, visiting the bank } \\
\text { website as the first website to receive services }\end{array}$} & Attitude stability & \multirow[b]{2}{*}{ Habit } \\
\hline & & Behavior stability & \\
\hline \multirow{2}{*}{$\begin{array}{l}\text { Geffen, 2003; } \\
\text { Paul et al., } 2009\end{array}$} & \multirow{2}{*}{$\begin{array}{l}\text { Bank good reputation between customers, bank good } \\
\text { reputation compared to other rival bank, website good } \\
\text { reputation for offering good services, website good } \\
\text { reputation about being fair in its relationship with its } \\
\text { users. }\end{array}$} & Bank reputation & \multirow[t]{2}{*}{ Reputation } \\
\hline & & Website reputation & \\
\hline \multirow{2}{*}{$\begin{array}{l}\text { Reichheld, 2000; Errol et } \\
\text { al., } 2005\end{array}$} & \multirow{2}{*}{$\begin{array}{l}\text { Bank's website meeting the customers, bank's not } \\
\text { being opportunist about customers, predictability of } \\
\text { bank's behavior, full recognition of customer and } \\
\text { market }\end{array}$} & Benevolence & \multirow{2}{*}{ Customer trust } \\
\hline & & Predictability & \\
\hline \multirow{3}{*}{$\begin{array}{l}\text { Smith, 2003; Ouyang, } \\
\text { 2010; Zeithaml \& Bitner, } \\
2000\end{array}$} & \multirow{3}{*}{$\begin{array}{l}\text { Bank's website meeting the customers' expectations, } \\
\text { customers considering it wise to use the website, } \\
\text { customer's general satisfaction with bank services, } \\
\text { considering the experience of using website services to } \\
\text { be satisfactory, understanding that the bank always } \\
\text { does its best to present services for customer's } \\
\text { satisfaction }\end{array}$} & $\begin{array}{l}\text { Expectations } \\
\text { rationalization }\end{array}$ & \multirow{3}{*}{ Customer satisfaction } \\
\hline & & General satisfaction & \\
\hline & & Experience & \\
\hline $\begin{array}{l}\text { Chang \& Chen, } \\
\text { 2009; Strauss \& Frost, } \\
\text { 2001; Ghane, } 2011\end{array}$ & $\begin{array}{l}\text { Positive attitude toward the website as the best one for } \\
\text { bank services, customer's belief in not changing his } \\
\text { priority in using website services, using website } \\
\text { services in future, continuous use of bank electronic } \\
\text { services in future, recommending it to others }\end{array}$ & $\begin{array}{l}\text { Behavioral } \\
\text { dimension }\end{array}$ & Customer loyalty \\
\hline
\end{tabular}




\section{Research method}

This research is an applied one intending to present a model for the factors influencing the establishment of customers' e-loyalty by means of the field method. Library studies were used to compile the theoretical principles of the research, and a questionnaire was used to respond its questions and explain its conceptual model. The viewpoints by the experts and studies on the research background were used to determine the validity of the data collection tools. Cronbach's alpha $(\alpha)$ coefficient was applied to measure the validity and reliability of the data collection tools. KaiserMeyer-Olkin (KMO) measure of sample adequacy was used to estimate data compatibility for factor analysis. To analyze the data, confirmatory factor analysis (CFA) method, and structural equation model (SEM) were used with LISREL and SPSS statistical software. The statistical population of the research includes the electronic customers of Mellat Bank. To conduct the CFA by means of simple random sampling and Cochran's method, its sample size involved 160 individuals.

\section{Research results}

\subsection{Descriptive analysis results}

In this research, descriptive analysis involved analyzing the demographic data, and estimating Cronbach's alpha and KMO coefficients. The results of the analysis of demographic data are shown in Table 2.

Table 2

Results of the analysis of demographic data

\begin{tabular}{|c|c|c|c|}
\hline property & Options & Frequency & Percent \\
\hline \multirow{2}{*}{$\operatorname{sex}$} & male & 85 & $53 \%$ \\
\hline & female & 75 & $47 \%$ \\
\hline \multirow{4}{*}{ age } & Less than 25 & 10 & $6 \%$ \\
\hline & $26-35$ & 91 & $57 \%$ \\
\hline & $36-45$ & 51 & $32 \%$ \\
\hline & More than 45 & 8 & $5 \%$ \\
\hline \multirow{4}{*}{ educational level } & diploma & 6 & $4 \%$ \\
\hline & associated degree & 23 & $14 \%$ \\
\hline & bachelor & 98 & $61 \%$ \\
\hline & MA & 33 & $21 \%$ \\
\hline \multirow{4}{*}{ experience of using e-banking } & under 6 month & 6 & $4 \%$ \\
\hline & between 6 month to 1 year & 24 & $15 \%$ \\
\hline & between 1year to 2year & 22 & $14 \%$ \\
\hline & more than 2 year & 108 & $67 \%$ \\
\hline
\end{tabular}

\section{Table 3}

Test results of Explicit indexes reliability

\begin{tabular}{lllll}
\hline Implicit structure & Indexes Explicit & Number of statements & KMO coefficient & $(\alpha)$ coefficient \\
\hline \multirow{3}{*}{ Service quality } & web design & $1-4$ quest & 0.79 & .75 \\
& customer service & $5-7$ quest & 0.74 & .73 \\
& assurance & $8-10$ quest & 0.74 & .74 \\
\hline Perceived value & economic value & $11-12$ quest & 0.76 & 0.72 \\
& relation value & $13-14$ quest & 0.71 & 0.75 \\
\hline \multirow{2}{*}{ Habit } & Attitude stability & $15-16$ quest & 0.73 & 0.79 \\
& Behavior stability & $17-18$ quest & 0.71 & 0.77 \\
\hline Reputation & Bank reputation & $19-20$ quest & 0.75 & 0.76 \\
& Website reputation & $21-22$ quest & 0.75 & 0.78 \\
\hline Customer trust & Benevolence & $23-25$ quest & 0.78 & 0.76 \\
& Predictability & $26-27$ quest & 0.76 & 0.76 \\
\hline Customer satisfaction & Expectations rationalization & $28-29$ quest & 0.72 & 0.82 \\
& General satisfaction & $30-31$ quest & 0.79 & 0.84 \\
& Experience & $32-33$ quest & 0.74 & 0.81 \\
\hline Customer loyalty & Attitude dimension & $34-37$ quest & 0.78 & 0.86 \\
& Behavioral dimension & $38-40$ quest & 0.76 & 0.83 \\
\hline
\end{tabular}


Results of analyzing the demographic data (including sex, age, etc.) showed that women form the highest sample membership (47\%). Moreover, most members of the sample size (57\%) fall within the range of 25 to 35 years of age. Considering educational level, bachelor's degree with a frequency of $61 \%$ had the highest sample size. Finally, regarding the experience of using e-banking, $67 \%$ had an experience of more than two years. To measure the reliability of using factor analysis, KMO and Cronbach's alpha $\left(\mathrm{r}_{\alpha}\right)$ coefficients were estimated. A numerical value, more than 0.5 , for the KMO coefficient denotes the utility of confidence coefficient for using factor analysis (Hinton et al., 2004). Also, a value of more than 0.8 for Cronbach's alpha coefficient showed that data collection tools have a suitable reliability. The test result of Explicit indexes reliability are shown in Table 3.

\subsection{Structural model results}

Exogenous implicit structures of the conceptual model include service quality (SQ), perceived value (PV), habit (HAB), and reputation (REPU). Results of estimating the parameters and calculating the standardized factor loads of the $\mathrm{X}$ factor model are shown in Fig. 3.
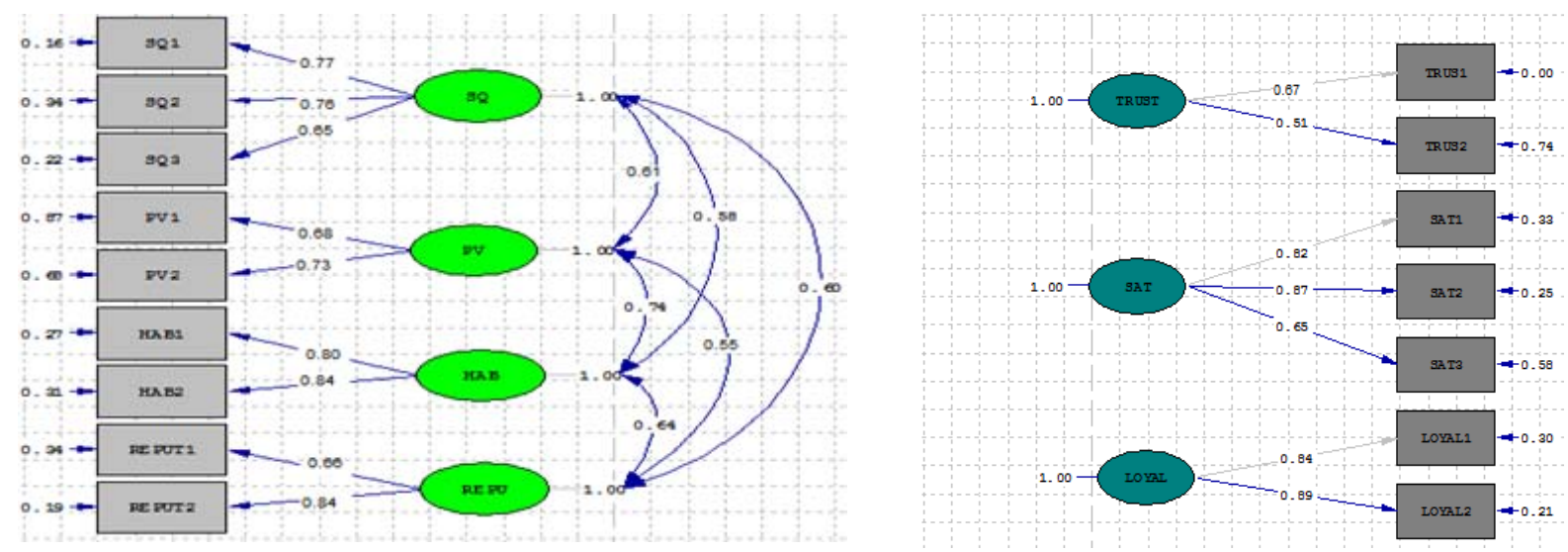

Chi-Square $=179.17, \mathrm{df}=88, \mathrm{P}-$ Value $=0.00000, \mathrm{RMSEA}=0.081$

Fig. 3. Standardized loads in X factor model

Fig. 4. Standardized loads in Y factor model

Results of estimating the parameters as well as $t$-statistic and diagnose coefficient are summarized in table 4. According to table 3, the values of diagnose coefficients $\left(R^{2}\right)$ for all factor loads, and their $t$ values are significant at 5\% error level. Results of estimating the coefficients of the routes between components of the structural model are shown in Fig. 5.

\section{Table 4}

Results of estimating parameters

\begin{tabular}{lllll}
\hline Implicit component & Explicit index & Standard value & $t$-statistic & Diagnose coefficient \\
\hline \multirow{3}{*}{ Service quality $(\mathrm{SQ})$} & $\left(\mathrm{SQ}_{1}\right)$ & 0.77 & 10.69 & $60 \%$ \\
& $\left(\mathrm{SQ}_{2}\right)$ & 0.76 & 10.42 & $58 \%$ \\
& $\left(\mathrm{SQ}_{3}\right)$ & 0.65 & 8.51 & $42 \%$ \\
\hline Perceived value(PV) & $\left(\mathrm{PV}_{1}\right)$ & 0.68 & 9.22 & 0.44 \\
& $\left(\mathrm{PV}_{2}\right)$ & 0.73 & 10.34 & 0.53 \\
\hline Habit & $\left(\mathrm{HAB}_{1}\right)$ & 0.80 & 10.72 & 0.64 \\
& $\left(\mathrm{HAB}_{2}\right)$ & 0.84 & 11.32 & 0.71 \\
\hline Reputation & $\left(\mathrm{REPU}_{1}\right)$ & 0.66 & 8.58 & 0.44 \\
& $\left(\mathrm{REPU}_{2}\right)$ & 0.84 & 11.05 & 0.71 \\
\hline \multirow{3}{*}{ Satisfaction } & $\left(\mathrm{SAT}_{1}\right)$ & 0.82 & 11.91 & 0.67 \\
& $\left(\mathrm{SAT}_{2}\right)$ & 0.87 & 12.77 & 0.75 \\
\hline Trust & $\left(\mathrm{SAT}_{3}\right)$ & 0.65 & 8.68 & 0.42 \\
\hline Loyalty & $\left(\mathrm{TRUS}_{1}\right)$ & 0.67 & 10.11 & 0.45 \\
& $\left(\mathrm{TRUS}_{2}\right)$ & 0.51 & 7.53 & 0.26 \\
\hline & $\left(\mathrm{LOYAL}_{1}\right)$ & 0.84 & 10.99 & 0.71 \\
\hline
\end{tabular}




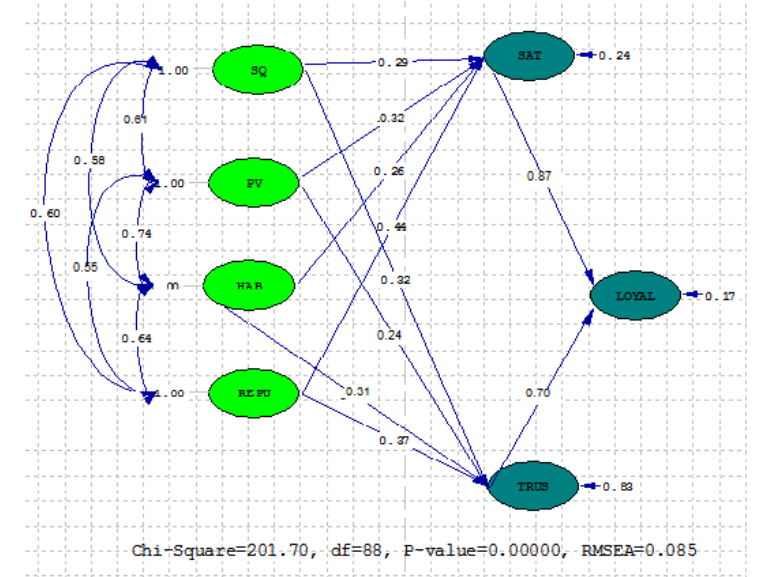

Fig. 5. Results of analyzing the structural relationship

In the structural model of diagram 5, RMSEA is 0.085 who's near-zero value shows good appraisal of the model. Results of studying the research hypotheses and estimating the relationships between the components of e-loyalty formation model are given in Table 5.

\section{Table 5}

Results of testing the hypotheses

\begin{tabular}{llllll}
\hline Hypothesis & Exogenous component & Endogenous component & Direct influence & $t$-statistic & Result \\
\hline 1 & Service quality (SQ) & Satisfaction (SAT) & 0.29 & 6.69 & accepted \\
2 & Perceived value(PV) & Satisfaction (SAT) & 0.32 & 7.22 & accepted \\
3 & Habit (HAB) & Satisfaction (SAT) & 0.26 & 5.72 & accepted \\
4 & Reputation(REPU) & Satisfaction (SAT) & 0.44 & 9.05 & accepted \\
5 & Service quality (SQ) & Trust(TRUS) & 0.32 & 7.56 & accepted \\
6 & Perceived value(PV) & Trust(TRUS) & 0.24 & 6.27 & accepted \\
7 & Habit (HAB) & Trust(TRUS) & 0.31 & 7.32 & accepted \\
8 & Reputation(REPU) & Trust(TRUS) & 0.37 & 7.87 & accepted \\
9 & Satisfaction (SAT) & Trust(TRUS) & 0.67 & 10.59 & accepted \\
10 & Satisfaction (SAT) & Loyalty(LOYAL) & 0.87 & 13.65 & accepted \\
11 & Trust(TRUS) & Loyalty(LOYAL) & 0.70 & 12.87 & accepted \\
\hline
\end{tabular}

Significance of $t$-values for all the hypotheses at 5\% error level shows that all the routes and relationships between the components are significant and all the hypotheses are, therefore, confirmed.

\section{Results and discussion}

Analyzing the results of factor models shows that "reputation" variable is the most important index influencing the "customer satisfaction" component with an influence coefficient of 0.44 . Moreover, "perceived value," and "service quality," with influence coefficients of 0.32 and 0.29 are the most important indexes influencing the "customer satisfaction" component, respectively. In addition, "customer trust" components including "reputation", "service quality" and "habit" with the coefficients of $0.37, .032$ and 0.31 are considered the most influential indexes, respectively. Therefore, it may be concluded that bank's good reputation with customers, good reputation compared with its competitor banks, good reputation of the website to provide proper services, and reputation of the website are all among the factors influencing customer satisfaction. In addition, suitability of service value compared with the cost paid for it, acceptability of the cost paid for the service, considering the received service as being valuable, and receiving the value added arising from bank's electronic services may influence customers' satisfaction with e-banking system through valuing them. In terms of trust development and attracting customer trust, it may be concluded that three main indexes including suitable design, providing services, and website reliability could be considered as effective indexes. Moreover, presenting the features and functions of services for users, updating website information, high rate of uploading web pages, providing comprehensive 
information about product features, fulfilling commitments within specific time limits for customers, providing customers with services as soon as possible, providing information about the accessibility of product/service on the web, confidentiality of customer's information, and providing customers with clear information about the process of interaction are all among the factors to which the bank should pay attention for trust development in customers and in banking.

The "benevolence" index with a diagnose coefficient of $45 \%$ has the first priority for influencing trust. Finally, customer's "positive attitude" towards the performance of the bank and its website, with a diagnose coefficient of $71 \%$, is described as the most important index to explain loyalty.

Analyzing the results from the structural model also reveals that satisfaction, with a direct influence of 0.87 , is the most significant factor in customer's loyalty formation in an electronic environment. Hence, considering the confirmation/disconfirmation theory of expectations and perceptions together with research structural model, it can be concluded the bank's attempts to rationalize customer's expectations and correspondence between the bank's website with his expectations is witnessed as a main factor in customer's satisfaction formation and, consequently, his loyalty. Moreover, considering the effect of trust on customer's loyalty, with a direct influence of 0.70, paying attention to trust development in customer and reinforcing customer trust from the viewpoint of attitude and behavioral dimensions, are vital factors for trust formation among the customers of e-banking.

\section{References}

Abasinejad, H., \& Mehrnoosh, M. ( 2006 ). Electronic Banking. Samt publications, $1^{\text {st }}$ ed., In Persian.

Akhter, W., Abbasi, A.S., Ali, L. \& Afzal, H. (2011). Factors affecting customer loyalty in Pakistan. African Journal of Business Management, 5(4), 1167-1174.

Beerli, A., Martin, J. D., \& Quintana, A. (2004). A model of customer loyalty in the retail banking market. European Journal of Marketing, 38(1/2), 253-275.

Bloemer, J., Ruyter, K., \& Peeters, P. (1998). Investigating Drivers of Bank Loyalty : the Complex Relationship Between Image , Service Quality and Satisfaction. International Journal of Bank Marketing . MCB University Press, 16(7), 276-286.

Castro, C.B., Armario, E.M., \& Ruiz, D.M. (2004). The influence of employee organizational citizenship behavior on customer loyalty. International Journal of Service Industry Management, 15 (1), 27-53.

Cohen, D., Gan, C., Au Yong, H. H., \& Choong, E. (2006). Customer satisfaction: a study of bank customer retention in New Zealand. Lincoln University.

Czepiel, J. A., \& Gilmore, R. (1987). Exploring the Concept of Loyalty in Services in The Service Challenge: Integrating for Competitive Advantage, C. Congram, JA Czepiel, and J. Shanahan, eds. Chicago: American Marketing Association.

Jansson, E., \& Letmark, M. (2009). Customer loyalty in Internet banking. Technical report, 1-59.

Joseph, E.E., Winston, B.E. (2005). A correlation of servant leadership, leader trust, and organizational trust. Leadership \& Organization Development Journal, 26(1), 6 - 22.

Gallarza, M \& Saura, I. (2006). Value dimensions, perceived value, satisfaction and loyalty: An investigation of university students travel behavior. Journal of Tourism Management, 27, 437-452.

Ghane, S., Fathian, M. \& Gholamian, M.R. ( 2011 ). Full relationship among e-satisfaction, etrust, e-service quality and e-loyalty: The case study of Iran e-banking. Journal of Theoretical and Applied Information Technology, 33(1), 1-6. 
Ivanov, A., Cyr, D., Hassanein, K., \& Head, M. (2007). The role of social presence in establishing loyalty in e-service environments. Interacting with Computers, 19(1), 43-56.

Kärnä, S., Junnonen, J. M., \& Sorvala, V. M. (2009). Modelling structure of customer satisfaction with construction. Journal of Facilities Management, 7(2), 111-127.

Larsson, S., \& Hjalte, S. ( 2004 ). Managing customer loyalty in the automobile industry. Ph.D. Lulea University of Technology. Sweden.

Methlie, L. B., \& Nysveen, H. (1999). Loyalty of on-line Bank Customers. Journal of Information Technology, 14, $375-386$.

Ordoubari, A. (1991). The Role of Educative Habit. Tehran, Hoda Publications, (In Persian).

Osman, H., Hemmington, N. \& Bowie, D. (2009). A transactional approach to customer loyalty in the hotel industry. International Journal of Contemporary Hospitality Management, 21(3), 239-250.

Ouyang, Y. (2010). Relationship between the Financial Consultants Service Quality and Customer Trust after Financial Tsunami. Journal of Finance and Economics, 36, 8586.

Messinger, P. R., Li, J., Stroulia, E., Galletta, D., Ge, X., \& Choi, S. (2009). Seven challenges to combining human and automated service. Canadian Journal of Administrative Sciences/Revue Canadienne des Sciences de l'Administration, 26(4), 267-285.

Parasuraman, A., Zeithaml, V.A., \& Berry, L.L. (1985). A conceptual model of service quality and its implications for future research. Journal of Marketing, 49(4), 41-50.

Parasuraman, A., Zeithaml, V.A., \& Berry, L.L. (1988). SERVQUAL: a multiple-item scale for measuring consumer perceptions of service quality. Journal of Retailing, 64(1), 12-40.

Reichheld, F.F., \& Schefter, P. (2000). Eloyalty: Your secret weapon on the Web. Harvard Business Review, 78(4), 105-114.

Smith, A.K., Shankar, V., \& Rangaswamy, A. (2003). Customer satisfaction and loyalty 11 in online and offline environments. International Journal of Research Marketing, 20(2), 153-175.

Stewart, K. (1999). Transference as a means of building trust in World Wide Web Sites. In Proceedings of the 20th ICIS, Charlotte, North Carolina.

Strauss, J., \& Frost, R. (2001). Marketing on the Internet. Prentice Hall, $3^{\text {rd }}$ ed.

Vahdat, D., \& Molaee Najafabadi, Z. ( 2002 ). Studying user interface and security in ebanking systems and their impact on customer satisfaction and loyalty. Information Technology Age, 52.

Ward, T., Al-Hawari, M., \& Newby, L., (2009). The relationship between service quality and retention within the automated and traditional contexts of retail banking. Journal of service Management, 20(4), 455-472.

Yee, B.Y., Faziharudean, T.M. (2010). Factors affecting customer loyalty of using internet banking in Malaysia. Journal of Electronic Banking Systems, Article ID 592297.

Zeithaml, V. A., Bitner, M. J., \& Gremier, D. D. (2006). Service Marketing: Integrating Customer Focus Across The Firm-4/E. McGraw Hill.

Zeithaml, V. A., Parasuraman, A., \& Malhotra, A. (2002). Service quality delivery through web sites: a critical review of extant knowledge. Journal of the academy of marketing science, 30(4), 362375 . 